\title{
Economic Assessment of Climate Adaptation Options in Myanmar Rice-Based Farming System
}

\author{
Yarzar Hein ${ }^{1,4}$, Kampanat Vijitsrikamol ${ }^{2}$, Witsanu Attavanich ${ }^{3} \&$ Penporn Janekarnkij ${ }^{2}$ \\ ${ }^{1}$ Doctor of Philosophy Program in Agricultural and Resource Economics (International Program), Graduate \\ School, Kasetsart University, Thailand \\ ${ }^{2}$ Department of Agricultural and Resource Economics, Kasetsart University, Thailand \\ ${ }^{3}$ Department of Economics, Kasetsart University, Thailand \\ ${ }^{4}$ Department of Agricultural Economics, Yezin Agricultural University, Myanmar \\ Correspondence: Yarzar Hein, Doctor of Philosophy Program in Agricultural and Resource Economics \\ (International Program), Graduate School, Kasetsart University, Thailand. E-mail: yarzarhein@yau.edu.mm
}

\author{
Received: February 1, $2019 \quad$ Accepted: March 3, $2019 \quad$ Online Published: April 15, 2019 \\ doi:10.5539/jas.v11n5p35 \\ URL: https://doi.org/10.5539/jas.v11n5p35
}

\begin{abstract}
Agriculture is highly sensitive to climate change and understandings how the adaptation options improve the farming household's adaptive capacity are critical to the agricultural policies. The study was carried out for the economic assessment of climate adaption options in rice-based farming system of Myanmar. The propensity score matching approach was applied to explore the existing adaptation options and its contribution on the farm income. In addition, the binary probit model was used to analyse the factors influencing those adaptation decisions. The erratic rainfall, especially dry spell period and unexpected rain during the critical crop growth, was the critical challenge of rice-based farming in the study. The timely operation of farm machineries was one of the major adaptation options for the farmers, followed by other options such as use of more agrochemicals and changing rice varieties including early maturity, high yielding and stress tolerant varieties. The combination of those adaptations gave additional 0.86-0.89 ton/ha yield, 152-158 USD/ha total return and 108-124 USD/ha profit to the adapter farmers. The institutional factors such as irrigation access, access to credit, access to weekly weather information and participation to agricultural training were critically important to the adaptation decision. Moreover, the social capital factors like farming experience, farm size and farm income share were also major influencing variables.
\end{abstract}

Keywords: climate adaptation, economic impact, Myanmar, propensity score matching, rice-based farming

\section{Introduction}

An inevitable challenge for the sustainable development of all countries is the climate change and its negative impacts today. Due to the climate change, Myanmar has been experiencing climate extremes like drought, flood, sea-level rise and natural disasters. The German watch's Climate Risk Index for 1995-2016 ranked Myanmar as the second most vulnerable country globally between Honduras and Haiti (Kreft, David, Lukas, \& Livia, 2016). Among four different geographical areas of Myanmar, the central dry zone (CDZ) area suffers a significant climate variability due to droughts and floods resulting to crops destruction and increased vulnerability of farm households. The severe drought that occurred in the CDZ significantly contributed to the agriculture sector losses of approximately 12 million USD in 1979, 9 million USD in 1982, and 16 million USD in 1993. Although the region has experienced long drought, unusual changes have been observed lately. The heavy rains triggered flash floods caused massive losses in the agriculture sector. Millions of acres of farm land had been inundated and thousands of sown acres were damaged with an estimated loss to about USD 271000 in 2010, 0.2 million USD in 2014, and 737 million USD in 2015 (Note 1). All these impacts set back sustainable development of the region and made the farming households vulnerable to climate variability.

Even though there is significant impact of climate stresses, the CDZ is an important and strategic area of the country's agriculture. It is the second leading rice producing region, providing $22 \%$ of the country's annual rice production requirements. It has 4.7 million ha of agricultural land and about 5.93 million metric tons of rice from the 2.1 million ha of rice area was produced in 2016. In those CDZ areas, two townships, ShweBo and KyautSe 
are the major rice producing areas and majority of the farmers on those areas relied on rice-based farming system. However, with the existing climate change, those farmers tried to adjust their farming activities by cropping system and crop calendar adjustment, water harvesting and water saving technologies, and so on. In cooperation with it, the Ministry of Agriculture, Livestock and Irrigation encourages the implementation of climate adaptation measures like system of rice intensification, alternate wetting and drying, use of stress-tolerant plant varieties, improved pest and weed management, better soil and water conservation practices, etc.

Despite of being vulnerable to climate variability, the local farming can cope with the negative climate change impacts to a certain extent. Some of local copping strategies are already adaptive to negative impacts of climate change. However, there is no evidence how much the farm households are resilient with these adaptation options in their farming activities. Thus, this research attempts to evaluate the climate adaptation options of rice-based farming systems in the study area.

The overall objective is to carry out the economic assessment of climate adaptation options on rice-based farming. Specifically, there are three objectives in this study; (i) to find out the current climate stresses in the farming system and their climate adaptation options, (ii) to examine the contribution of existing adaptation options on the farm income of the households and (iii) to determine the factors influencing the farmers' adaptation decision by social capital and institutional aspects.

\subsection{Climate Adaptation Strategies in Agriculture}

Adaptation is a process through which societies enable themselves to cope better with uncertain future by the right measures to reduce the negative effects of climate change (UNFCCC, 2007). With the existing climate change impacts, the agricultural adaptions in southeast Asia countries are intended to increase adaptive capacity by modifying farming practices, improving crops and livestock through breeding and investing in new technologies and infrastructure. The specific agriculture adaptations are adjusted by (1) the choice of crop and cultivar including use of more heat/drought-tolerant varieties in areas under water stress, use of more disease and pest tolerant crop varieties, introduce higher yielding, earlier maturing crop varieties and (2) farm management such as altered application of agrochemicals, change planting date to effectively use the prolonged growing season and irrigation (IPCC, 2007).

Regarding the climate adaptation strategies, there are four main categories to the adaptation options in agricultural farming: (1) technological developments such as crop development and weather and climate information systems, (2) government programs (agricultural subsidy and support programs) and insurance, (3) farm production practices including land use, irrigation and timely operations, and (4) farm financial management (Barry \& Mark, 2002). Changing farm production activities have the potential to reduce exposure to climate-related risks and increase the flexibility of farm production to changing climatic conditions (Chiotti, Johnston, Smit, \& Ebel, 1997). Changing crop variety, intensification of irrigation, water-harvesting scheme, crop diversification, and crop calendar adjustment are the most significant agricultural adaptation options to climate change (Aymone Gbetibouo, 2009; Gutu, Bezabih, \& Mengistu, 2012). For its impacts, Huang, Y. Wang, and J. Wang (2015) found that these adaptive measures led the farmers to be more resilient to climate change. Farmers who adapt to climate change get less yield loss (43\%) and reduce risk (69\%) than the non-adapters.

The study of Gebrehiwot and van der Veen (2013) employed crop diversification, soil conservation, irrigation application, changes in planting date and planting trees in the farm as the effective adaptation options on agriculture to climate change, by using multinomial logit (MNL) model. Results of the MNL indicated that most of the household variables, as well as wealth attributes, availability of information, agroecological features, and temperature influenced adaptation to climate change. Several studies of farmers' adaptation to climate change (Aymone Gbetibouo, 2009; Di Falco, Veronesi, \& Yesuf, 2011; Gutu et al., 2012; Huang et al., 2015) proved that institutional factors such as accurate weather information, agricultural credit, irrigation, extension service, and non-institutional factors like educational level of farmer, age, awareness on climate change, are the determinants of adaptation decisions. Improving farmers' access to those institutional and non-institutional factors facilitates them to adapt climate change.

As per Myanmar Climate Smart Agricultural Strategy, climate adaptation measures such as developing stress resistant crop varieties and corresponding agricultural practices that encourages the climate smart farming management are national priority adaptation programs of country and recognized as one of the policy options and strategies to reduce the negative impact of climate change (Nang, Nyo Mar, Yarzar, \& Shwe Mar, 2015). In the dryzone agriculture, the scarce and erratic rainfall was the serious hazards of climate variability and low productivity of crop made the vulnerability of farm households. To adapt these negative impacts, changing of sowing time, more utilization of agrochemicals and crop diversification became the adaption options in dry zone 
farming (Nang Eimon \& Cho Cho, 2012). Moreover, Tun Oo, Van Huylenbroeck, and Speelman (2017) also found that the adjustment of sowing time and crop diversification were the major adaptation options in the dry zone. According to the study of Rajendra, Nani, Lwin, and Thida (2018), the farmers in the dry zone of Myanmar practiced crop diversification and cropping calendar method to adapt the changing precipitation pattern. In addition, they utilized more agrochemicals such as chemical fertilizers for declining soil productivity, and pesticide for pest and disease outbreak as a consequent of climate change.

Climate change affect the farmer's livelihood negatively by affecting productivity and net farm income through reduced per hectare crop yields (Abid, Scheffran, Schneider, \& Ashfaq, 2015; Philip Antwi-Agyei, Stringer, \& Dougill, 2014). Although a number of studies related to farmers' adaptation to climate change exist, there is inadequate analysis on the effectiveness of adaptation practices on yield and income stability. El-Shater et al. (2016) found that adaptive farming practice (zero tillage) increases net income by $33 \%$ and this adaptation led to the improvement of the livelihoods in term of net farm income and per capital consumption.

\section{Research Methodology}

\subsection{Study Area and Data Collection}

The study was carried out in the major rice area of the Central Dry Zone which is strategically important for the country agriculture and suffers drought and flood events. Based on rice production statistics of Department of Agriculture, two townships in the upper CDZ, ShweBo Township from Sagaing region and KyautSe Township from Mandalay region, were chosen as the study area. Agricultural land in ShweBo Township in 2016 was 81019 ha and total rice area was 48833 ha. The monsoon rice area under irrigation schemes was 38673 ha and rainfed monsoon rice area was 8910 ha, while the irrigated rice in summer season was 23388 ha. In KyautSe Township, the rice area was 30645 ha which was about $57 \%$ of the township's agricultural land $(53,041$ ha). There were 22268 ha of irrigated monsoon rice, 5009 ha of rainfed monsoon rice and 7344 ha of summer irrigated rice in 2016.

Secondly, the purposive sampling was employed in selecting village tracts from each township, based on extent of rice area. 3 villages from rainfed ecosystem and another 3 villages from irrigated ecosystem were chosen in each township.

Then, in the selection of sample farm households, stratified random sampling method was used. Normally, there is an average of 150 to 200 rice farming households per village in the study area. According to the farmer population lists of Department of Agriculture and General Administrative Department, $20 \%$ of rice farming households in selected village were randomly chosen in three farm categories such as small, medium and large-scale farms. Although 300 farm households were selected, only 289 samples were effective for data analysis: 96 farm households of ShweBo and 87 farm households in KyautSe for irrigated agriculture, and 50 farms in ShweBo 56 farms in KyautSe under rainfed condition, as almost the same ratio to the percentage of irrigated and rainfed-farm households in each township.

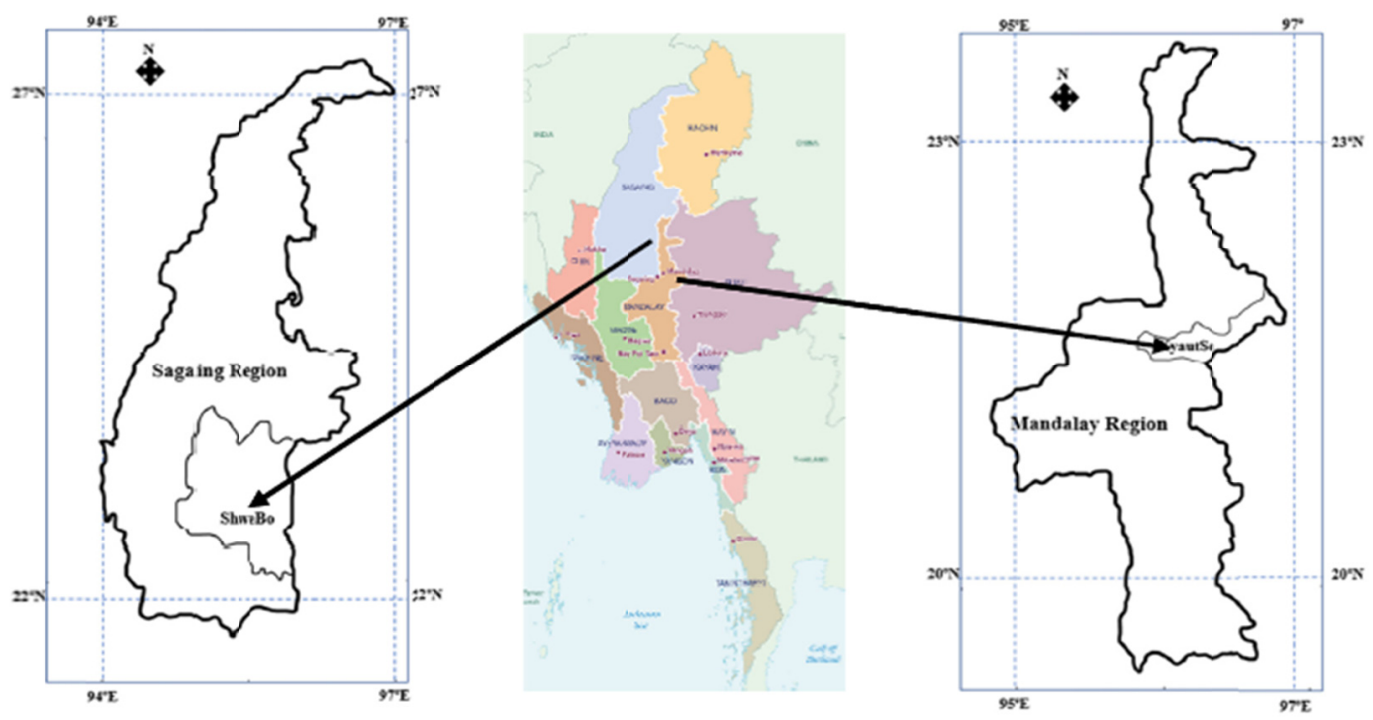

Figure 1. Study area map: (a) ShweBo Township in Sagaing Region and (b) KyautSe Township in Mandalay Region, Myanmar 


\subsection{Theoretical Model and Empirical Tools}

\subsubsection{Adaptation Decision}

Basically, the agricultural adaptation to climate variability is modelled as a choice between two alternatives: 'use of adaptation method' and 'no adaptation', by choosing the alternative that maximizes their perceived utility. It is expected that farmers will decide to use the adaptation option when the expected utility of adaptation $(D=1)$ is greater than the utility of not choosing $(\mathrm{D}=0)$.

In this study, choosing adaptation option $j$ is a dichotomous choice: $D_{j}=1$, if $U_{j t}=V_{j t}+\varepsilon_{j t}>U_{k t}=V_{k t}+\varepsilon_{k t}$, where $U_{j}$ and $U_{k}$ are the perceived utility from choosing an alternative $j$ and $k$ at time $t$ respectively, $V_{j t}=\beta_{j} x_{n t}$ and $V_{k t}=\beta_{k} x_{n t}$ are the deterministic component and $\varepsilon_{j t}$ and $\varepsilon_{k t}$ are the random components (or error terms) of the utility function, which are assumed to be independently and identically distributed.

Then, the probability of individual $m$ choosing alternative $j$ among the set of adaptation options at time $t$ can then be specified as $P_{m j t}\left(D_{j}=1 \mid X\right)=P\left(V^{*}+\varepsilon^{*}>0 \mid X\right)$, where, $\mathrm{P}$ is a probability function, $\varepsilon^{*}=\varepsilon_{j t}-\varepsilon_{k t}$ is the stochastic component, $V^{*}$ is the deterministic components with a vector of unknown parameters which can be interpreted as the net influence of the vector of independent variables influencing adoption.

Depending on the assumed distribution that the random disturbance terms follows, several qualitative choice models such as a linear probability model, a logit model or probit model could be estimated (Greene, 2000). Based on this dichotomous choice model, the endogenous switching regression will be written as the following (El-Shater et al., 2016): $Y_{1}=X_{1} \omega_{1}+\epsilon_{1}$, if $D_{j}=1$ and $Y_{0}=X_{0} \omega_{0}+\epsilon_{0}$, if $D_{j}=0$, where, $Y_{i}$ is a vector of dependent variables representing outcomes for adapters $\left(Y_{I}\right)$ and non-adapters $\left(Y_{0}\right), X_{i}$ is a matrix of explanatory variables, $\omega_{i}$ is a vector of parameters to be estimated, and $\epsilon_{1}$, and $\epsilon_{0}$ are error terms. This study applied the probit model to find out the factors influencing farmers' decision to adaptation options and the hypothesized model for the determinants of local farmer's adaptation choice become as followed,

$$
A D S=\alpha_{0}+\alpha_{1} S Y F+\alpha_{2} R F E+\alpha_{3} F F L+\alpha_{4} H D R+\alpha_{5} F S H+\alpha_{6} F I S+\alpha_{7} A T I+\alpha_{8} A T C+\alpha_{9} P A T+\alpha_{10} A T W+\varepsilon(1)
$$

where, $\mathrm{ADS}=$ Adaptation Status $(1=$ Adoption of specific adaptation measure, $0=$ otherwise $)$; SYF $=$ Schooling years of farmer (years); RFE $=$ Rice farming experience (years); FFL $=$ Family farm labor (no.); HDR = Household dependency ratio; FSH = Farm size (ha); FIS = Farm income share ( $\%$ of total family income); ATI = Access to irrigation ( $\%$ of farm size under irrigation scheme); ATC $=$ Access to credit/loan (amount of credit/loan in USD); PAT = Participation on agricultural training (frequency); ATW = Access to weekly weather focus (Yes $=1, \mathrm{No}=0$ ).

\subsubsection{Economic Impact Evaluation by Propensity Score Matching Approach}

Impact evaluation resulted to whether changes in well-being are indeed due to the program intervention or adoption of a technology and not to other factors (Khandker, 2010). To determine the contribution of adaptation options to farm income, this study applied propensity score matching (PSM) model, which can show effectiveness of an adaptation option when the farmer choose, and it can determine what happen if they do not choose that specific adaptation option.

PSM compares the benefits gained by the farmers after they choose a certain adaptation measure. Comparisons can be made over time or in space or a combination of both. It helps to generate valid counterfactuals from a non-random sample and it is used to select reliable counterfactuals from a large pool of conventional farmers in an area with similar conditions (Priyanka \& Herman, 2015). PSM attempts to reduce selection bias due to confounding variables that can be found in the treatment effect estimates obtained by simply comparing the outcomes between treatment units versus those that did not.

PSM constructs a statistical comparison group, based on a model of probability of adoption in the practice A conditional on observed characteristics $X$, or the propensity score: $P=\operatorname{Pr}(A=1 \mid X)$. Rosenbaum (1983) described that matching on $P$ is as good as matching on $X$ under certain assumptions. The necessary assumptions for identification of the adaptation effect are (a) conditional independence and (b) presence of a common support.

If conditional independence holds and if there is a sizable overlap in $P(X)$ across adapters and non-adapters, the PSM estimator can be specified as the mean difference in $Y$ over the common support, weighting the comparison units by the propensity score distribution of adapters. A typical cross-section estimator can be specified as follows:

$$
A T T_{P S M}=E_{P \mid A=1}\left[E\left(Y_{1} \mid A=1, P\right)-E\left(Y_{0} \mid A=0, P\right)\right]
$$

ATT is average treatment effect on the treated group, simply stated the impact of using specific adaptation practice to the adaptors of that practice. 
Based on the probability or propensity score, adopters are matched to non-adopters. The average treatment effect of specific adaptation option is then calculated as the mean difference in outcomes across these two groups. Although there are three treatment effects of PSM approach; Average Treatment Effect (ATE), Average Treatment Effect on the Control (ATC) and Average Treatment Effect on the Treated (ATT), this article only emphasizes on Average Treatment Effect on the Treated (ATT) and it can be written as followed.

$$
A T T=E\left(Y_{1}-Y_{0} \mid A=1\right)=E\left(Y_{1} \mid A=1\right)-E\left(Y_{0} \mid A=1\right)
$$

In Equations (2) and (3), $A T T$ is average treatment effect on the treated group, and $E($.$) represents the expectation$ in the population. $Y_{i}$ denotes the farmer's decision with a value of 1 for adoption and the value of 0 for non-adoption. $A$ denotes the treatment with the value of 1 for the treated group and the value of 0 for the control group.

Examining the contribution of farmer's practices of climate adaptation to the farm income, three matching methods of PSM (Nearest Neighbor; the Radius and the Kernel) were used in this study.

Nearest neighbor: It is the most frequently used matching technique of PSM. In this matching, the individual from the comparison group is chosen as a matching partner for a treated individual that is closest in terms of propensity score, meaning that the adopter is matched to the comparison unit (non-adopter) with the closest propensity score. One can choose $n$ nearest neighbors and do matching.

Radius matching: One problem with nearest neighbor is that the difference in propensity scores for the adopters and its closest non-adopter neighbor may be very high, causing poor matches. To avoid such situation, setting a threshold or tolerance on the maximum propensity score distance (radius or caliper) and within a certain range of propensity score, the matching of adopter and non-adopter can be done.

Kernel matching: It is non-parametric matching estimators that use weighted averages of all individuals in the control group (non-adopter) to construct the counterfactual outcome. Weights depend on the distance between each individual from the non-adopter and the adopter observation for which the counterfactual is estimated.

In this study, with these matchings, the outcome variables were profit (USD/ha), total return (USD/ha), total variable cost (USD/ha) and productivity ( $\mathrm{t} / \mathrm{ha}$ ) of the rice production.

\section{Results and Discussion}

\subsection{Climatic Stress and Farmers Adaptation Strategies}

Table 1 presents the observed climate stresses in the study area. There were three types of climate stress observed in the farming system: (a) dry spell period during crop growing season, (b) unexpected rain during critical crop growth stages and (c) serious flood during crop season.

Table 1. Observed climate stresses

\begin{tabular}{|c|c|c|c|c|c|c|}
\hline & \multicolumn{2}{|c|}{ Total Sample } & \multicolumn{2}{|c|}{ Irrigated-farm Households } & \multicolumn{2}{|c|}{ Rainfed-farm Households } \\
\hline & No. & $\%$ & No. & $\%$ & No. & $\%$ \\
\hline Unexpected rain (UER) during critical crop growth & 257 & 88.93 & 156 & 85.25 & 101 & 95.28 \\
\hline Dry spell period (DSP) during crop growing season & 127 & 50.87 & 50 & 27.32 & 97 & 91.51 \\
\hline Flood event during the growing season & 207 & 71.61 & 158 & 86.34 & 49 & 46.23 \\
\hline
\end{tabular}

As regards to the climate stress occurred by the local farming households, $88 \%$ of sample households were facing unexpected rain during critical growth stages, while $73 \%$ of farm households encountered flood event during growing season and $56 \%$ of farms were affected by dry spell period during crop season. Then, based on the different levels of climate stresses, there were nine indicators of climate stress observed in the study (Figure 2.).

In irrigated farming, $42 \%$ of farming households suffered high frequency of unexpected rain which occurred almost every season, and 36\% of irrigated-farms experienced unexpected rain in every 3-4 crop seasons interval. Similarly, in the rainfed farming, $27 \%$ of farms were challenged by high frequency of unexpected rain and $67 \%$ suffered one time in every 3-4 crop seasons. It is observed that both irrigated and rainfed-farm households suffered unexpected rain during the critical growth stages of crop.

The dry spell period (DSP) during crop season were ranked as three conditions: longer DSP which last for more than 45 days in a growing season, average DSP for about 30-45 days, and short DSP for less than 30 days. The 
rainfed farming households were most affected by these conditions. $69 \%$ of rainfed-farms experienced longer DSP during the growing season and 25\% experienced average DSP stress. For the irrigated-farms, there were very few reports of farmers on DSP stress (only 10\%), since they had access to irrigation water for farming.

For the flood event, $55 \%$ of the irrigated farm households and $30 \%$ in rainfed-farm households in the study area experienced unexpected flood event in every three to four crop seasons interval.

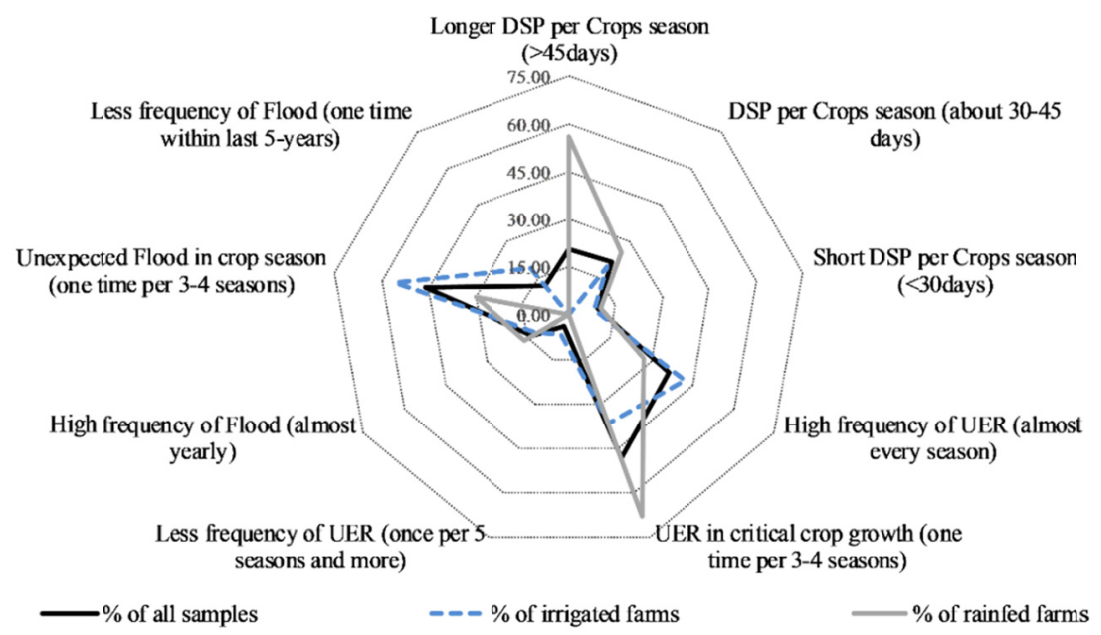

Figure 2. Different levels of climate stress observed by the farm households

The study found that unexpected rain was the major climatic stress for irrigated and rainfed-farms, while dry spell period was an additional stress to the rainfed farmers. To adopt with these climate stresses, the local farming households adjusted their farming activities. There were six major agricultural adaptation strategies of local farm households, except system of rice intensification (Figure 3).

(i) Crop calendar adjustment: it was observed that $20 \%$ of sample farmers or $55 \%$ of rainfed-farm households were using crop calendar adjustment to manage sowing and harvesting time, with the purpose of avoiding dry spell period during the critical growth stages and heavy rain in harvest time. However, the irrigated farm households did not necessarily adjust it since their farming activities were mainly depended on the irrigation schedule of Department of Irrigation.

(ii) Changes of rice varieties including use of short-duration varieties and drought resistant varieties: $36 \%$ of sample farm households were using short-duration varieties and only $11 \%$ of sample households used the drought resistant varieties in the study. Specifically, $63 \%$ of rainfed-farm households and $21 \%$ of irrigated-farms changed the early maturity rice varieties and $30 \%$ of rainfed-farms changed the drought resistant varieties.

(iii) Changes in cropping pattern: it was observed that $36 \%$ of rainfed-farms and very few percent of irrigated-farms followed the cropping pattern changes. In those farms of rainfed agriculture, onion, groundnut and tomato were widely grown alternatively based on the feasibility of ground water condition in post monsoon season. Growing sesame, groundnut, green-gram for summer crop season was alternative solution for the summer rice if there was not enough irrigation water source in irrigated-farms.

(iv) Use of more agrochemicals such as chemical fertilizer, pesticide and insecticide: About $58 \%$ of total farm households, specifically $63 \%$ of rainfed-farms and $51 \%$ of irrigated-farms, used more agrochemicals than before, to overcome the productivity losses due to unpredicted climate stresses. In that case, $46 \%$ of irrigated farmers and $16 \%$ of rainfed farmers applied more chemical fertilizers than the last five years' condition. In comparison with recent years, $63 \%$ of rainfed-farm households and $51 \%$ of irrigated farm households were using more chemical pesticide and insecticide than before.

(v) More investment in irrigation water: In facing with water scarcity and uncertain rain, about $20 \%$ of rainfed-farm households made more investment in irrigation, such as ground water utilization or access to irrigation from local earthen small dam. However only $8 \%$ from irrigated farm households invested more in additional irrigation source or better irrigation management. 
(vi) Use of farm machineries for timely operations: it was widely practiced in the study area. About $68 \%$ of all sample farm households ( $83 \%$ irrigated and $42 \%$ rainfed-farm households) were using farm machineries in the farming activities, especially during land preparations and harvesting of the crop, to capture enough soil moisture and irrigation water for sowing time and avoid heavy rain in harvesting time. Sometimes, it was necessary to replant crops if the weather was unfavorable after sowing. In this case, use of farm machineries made the farm management to be in time.

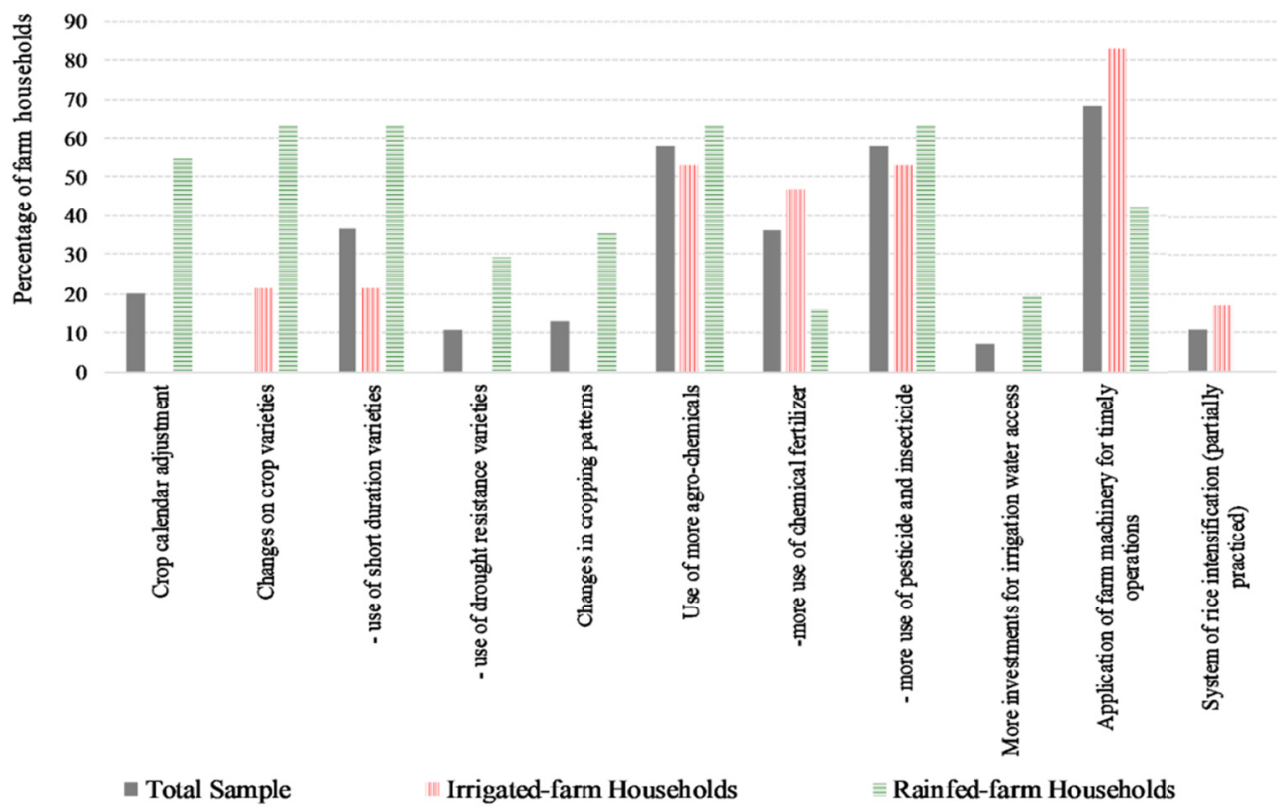

Figure 3. Farm household's agricultural adaptation practices to climate stresses

Meanwhile, Department of Agriculture promoted system of rice intensification (SRI) method and it was also counted as one of adaptation strategies in the study area. However, it was observed that only $16 \%$ of irrigated farm households follow the growing of young-seedlings practice as SRI component and did not apply the whole package of SRI technology as there were some limitations.

Table 2. Adaptation options for the application of propensity score matching (PSM)

\begin{tabular}{lll}
\hline Adaptation strategies & Adapter & Non-adapter \\
\hline 1. Use of farm machineries for timely operations & 197 & 92 \\
2. Use of more agrochemicals & 168 & 121 \\
3. Changes of rice varieties & 106 & 183 \\
4. Combination of above three options & 96 & 193 \\
\hline
\end{tabular}

Adaptations options such as crop calendar adjustment, changes of rice varieties, cropping pattern changes and use of more agrochemicals are consistent with other dryzone studies (Nang Eimon \& Cho Cho, 2012; Rajendra et al., 2018; Tun Oo et al., 2017). However, unlike their studies, there is two more specific adaptations for this area; use of farm machineries for timely operations and additional investment in irrigation water. Among the adaptation options observed in the study areas, three major practices were chosen based on (a) the crop area under that practice and (b) the year of adoption of the farms. These major practices were: (i) use of farm machineries for timely operations, (ii) use of more agrochemicals, and (iii) changes of rice varieties (Table 2). In this study, the impact of agricultural adaptation options on farm income were examined not only by these individual practices but also by the combination of those practices.

\subsection{Descriptive Analysis on Socioeconomic Characteristics of Adapter and Non-adapter Farmers}

The results of descriptive analysis on the socioeconomic characteristics of adapter and non-adapter farmers were shown in Tables 3 and 4. Regarding the first adaptation options, 197 farm households used farm machineries for 
timely operations especially during land preparation and harvesting, and 92 farm households did not use it. For the differences in characteristics of adapter and non-adapter farms, the study observed that farm size and access to irrigation of adapters was higher than non-adapter group, statistically significant at 5\% level. The average farm size of adapter group was 3.0 ha, while that of non-adapter group was 2.15 ha. For the access to irrigation, $71 \%$ of the agricultural land was under irrigation scheme in the adapter group, however, $49 \%$ of farm land accessed irrigation in the non-adapter group.

Table 3. Adapter and non-adapter's socioeconomic descriptive analysis

\begin{tabular}{|c|c|c|c|c|c|c|c|c|c|}
\hline & \multicolumn{3}{|c|}{ Farm machinery application } & \multicolumn{3}{|c|}{ Use of more agrochemicals } & \multicolumn{3}{|c|}{ Change of Rice Varieties } \\
\hline & $\begin{array}{l}\text { Adapters } \\
(197)\end{array}$ & $\begin{array}{l}\text { Non-adapters } \\
(92)\end{array}$ & $\begin{array}{l}\mathrm{P} \\
\text { value }\end{array}$ & $\begin{array}{l}\text { Adapters } \\
(168)\end{array}$ & $\begin{array}{l}\text { Non-adapters } \\
(121)\end{array}$ & $\begin{array}{l}\mathrm{P} \\
\text { value }\end{array}$ & $\begin{array}{l}\text { Adapters } \\
(106)\end{array}$ & $\begin{array}{l}\text { Non-adapters } \\
(183)\end{array}$ & $\begin{array}{l}\mathrm{P} \\
\text { value }\end{array}$ \\
\hline Age of farmer (years) & $\begin{array}{l}53.18 \\
(28.00-74.00)\end{array}$ & $\begin{array}{l}51.05 \\
(32.00-74.00)\end{array}$ & 0.1143 & $\begin{array}{l}49.35 \\
(28.00-74.00)\end{array}$ & $\begin{array}{l}52.05 \\
(32.00-74.00)\end{array}$ & 0.4165 & $\begin{array}{l}49.18 \\
(28.00-69.00)\end{array}$ & $\begin{array}{l}51.02 \\
(32.00-74.00)\end{array}$ & 0.6137 \\
\hline $\begin{array}{l}\text { Schooling years of } \\
\text { farmer (years) }\end{array}$ & $\begin{array}{l}8.05 \\
(0.00-16.00)\end{array}$ & $\begin{array}{l}6.50 \\
(0.00-11.00)\end{array}$ & 0.8107 & $\begin{array}{l}8.86 \\
(0.00-16.00)\end{array}$ & $\begin{array}{l}5.98 \\
(0.00-10.00)\end{array}$ & 0.0775 & $\begin{array}{l}5.94 \\
(0.00-16.00)\end{array}$ & $\begin{array}{l}5.58 \\
(0.00-14.00)\end{array}$ & 0.4068 \\
\hline $\begin{array}{l}\text { Rice farming experience } \\
\text { (years) }\end{array}$ & $\begin{array}{l}33.50 \\
(3.00-56.00)\end{array}$ & $\begin{array}{l}29.00 \\
(3.00-55.00)\end{array}$ & 0.5907 & $\begin{array}{l}31.00 \\
(3.00-56.00)\end{array}$ & $\begin{array}{l}32.50 \\
(3.00-56.00)\end{array}$ & 0.9148 & $\begin{array}{l}32.71 \\
(3.00-56.00)\end{array}$ & $\begin{array}{l}31.89 \\
(3.00-55.00)\end{array}$ & 0.6091 \\
\hline $\begin{array}{l}\text { Non-rice farming } \\
\text { experience (years) }\end{array}$ & $\begin{array}{l}13.00 \\
(2.00-30.00)\end{array}$ & $\begin{array}{l}15.65 \\
(2.00-30.00)\end{array}$ & 0.3206 & $\begin{array}{l}12.00 \\
(2.00-30.00)\end{array}$ & $\begin{array}{l}13.57 \\
(2.00-30.00)\end{array}$ & 0.7562 & $\begin{array}{l}11.49 \\
(4.00-29.00)\end{array}$ & $\begin{array}{l}14.78 \\
(2.00-30.00)\end{array}$ & 0.1968 \\
\hline $\begin{array}{l}\text { Livestock farming } \\
\text { experience (years) }\end{array}$ & $\begin{array}{l}3.95 \\
(0.00-7.00)\end{array}$ & $\begin{array}{l}4.05 \\
(0.00-9.00)\end{array}$ & 0.2135 & $\begin{array}{l}4.15 \\
(0.00-9.00)\end{array}$ & $\begin{array}{l}3.56 \\
(0.00-9.00)\end{array}$ & 0.1056 & $\begin{array}{l}3.38 \\
(0.00-6.00)\end{array}$ & $\begin{array}{l}4.56 \\
(0.00-9.00)\end{array}$ & 0.9122 \\
\hline Family member (no.) & $\begin{array}{l}4.05 \\
(2.00-7.00)\end{array}$ & $\begin{array}{l}4.59 \\
(2.00-8.00)\end{array}$ & 0.4175 & $\begin{array}{l}4.25 \\
(2.00-8.00)\end{array}$ & $\begin{array}{l}4.14 \\
(2.00-7.00)\end{array}$ & 0.7918 & $\begin{array}{l}4.87 \\
(2.00-8.00)\end{array}$ & $\begin{array}{l}4.42 \\
(2.00-7.00)\end{array}$ & 0.5861 \\
\hline Family farm labor (no.) & $\begin{array}{l}2.50 \\
(1.00-5.00)\end{array}$ & $\begin{array}{l}2.25 \\
(1.00-5.00)\end{array}$ & 0.7110 & $\begin{array}{l}2.50 \\
(1.00-5.00)\end{array}$ & $\begin{array}{l}2.15 \\
(1.00-5.00)\end{array}$ & 0.2165 & $\begin{array}{l}2.25 \\
(1.00-4.00)\end{array}$ & $\begin{array}{l}2.35 \\
(1.00-5.00)\end{array}$ & 0.6090 \\
\hline Non-farm employee (no.) & $\begin{array}{l}1.40 \\
(1.00-2.00)\end{array}$ & $\begin{array}{l}1.15 \\
(1.00-2.00)\end{array}$ & 0.4190 & $\begin{array}{l}1.20 \\
(1.00-2.00)\end{array}$ & $\begin{array}{l}1.13 \\
(1.00-2.00)\end{array}$ & 0.1960 & $\begin{array}{l}1.14 \\
(1.00-2.00)\end{array}$ & $\begin{array}{l}1.25 \\
(1.00-2.00)\end{array}$ & 0.6049 \\
\hline $\begin{array}{l}\text { Household } \\
\text { dependency ratio }\end{array}$ & $\begin{array}{l}0.40 \\
(0.00-0.75)\end{array}$ & $\begin{array}{l}0.65 \\
(0.00-0.80)\end{array}$ & 0.2189 & $\begin{array}{l}0.60 \\
(0.00-0.80)\end{array}$ & $\begin{array}{l}0.55 \\
(0.00-0.80)\end{array}$ & 0.1117 & $\begin{array}{l}0.43 \\
(0.00-0.75)\end{array}$ & $\begin{array}{l}0.43 \\
(0.00-0.80)\end{array}$ & 0.9271 \\
\hline Farm Size (ha) & $\begin{array}{l}3.00 \\
(0.81-12.95)\end{array}$ & $\begin{array}{l}2.15 \\
(0.81-12.95)\end{array}$ & 0.0288 & $\begin{array}{l}3.66 \\
(0.81-12.95)\end{array}$ & $\begin{array}{l}3.15 \\
(0.81-12.95)\end{array}$ & 0.2191 & $\begin{array}{l}3.21 \\
(0.81-12.95)\end{array}$ & $\begin{array}{l}2.04 \\
(0.81-12.95)\end{array}$ & 0.0317 \\
\hline $\begin{array}{l}\text { Access to irrigation } \\
\text { ( } \% \text { of farm size })\end{array}$ & $\begin{array}{l}71 \\
(0.00-100.00)\end{array}$ & $\begin{array}{l}49.00 \\
(0.00-100.00)\end{array}$ & 0.0476 & $\begin{array}{l}0.86 \\
(0.00-100.00)\end{array}$ & $\begin{array}{l}0.43 \\
(0.00-100.00)\end{array}$ & 0.0791 & $\begin{array}{l}82 \\
(0.00-100.00)\end{array}$ & $\begin{array}{l}56.00 \\
(0.00-100.00)\end{array}$ & 0.0476 \\
\hline
\end{tabular}

Note. The values in parentheses are the range of respective variables.

Concerned with the rice production of both groups, it was found that yield per hectare in monsoon period was $4.18 \mathrm{t} / \mathrm{ha}$ for adapter group and $3.12 \mathrm{t} / \mathrm{ha}$ for non-adapter. The total returns per hectare in monsoon rice production was $956 \mathrm{USD} / \mathrm{ha}$ in adapter group and $789 \mathrm{USD} / \mathrm{ha}$ in another group. The benefit cost ratios for monsoon rice were 1.78 in adapter group and 1.43 in non-adapter group. And these variables were statistically significant.

The second major adaptation option in the study area was use of agrochemicals as the prevention to crop losses during unfavorable weather changes and consequently pest and diseases outbreak. It was observed that 168 sample farm households used more agrochemicals than last five years. It was observed that access to irrigation of adapter group was higher than that of the non-adapter group and statistically significant at $10 \%$ level. Moreover, about $86 \%$ of the adapter's agricultural land was under irrigation scheme, but $49 \%$ of non-adapter's farm land accessed irrigation. The rice yields were $4.13 \mathrm{t} / \mathrm{ha}$ for the adapters and $4.0 \mathrm{t} / \mathrm{ha}$ for the non-adapter group. Total variable cost per hectare of rice production were $502 \mathrm{USD} /$ ha and $433 \mathrm{USD} / \mathrm{ha}$ in adapter and non-adapter groups respectively. Other economic variables such as profit and benefit cost ratio for the monsoon rice of both groups were not statistically significant. 
Table 4. Adapter and non-adapter's monsoon rice production descriptive analysis

\begin{tabular}{|c|c|c|c|c|c|c|c|c|c|}
\hline & \multicolumn{3}{|c|}{ Farm machinery application } & \multicolumn{3}{|c|}{ Use of more agrochemicals } & \multicolumn{3}{|c|}{ Change of Rice Varieties } \\
\hline & Adapters (197) & $\begin{array}{l}\text { Non-adapters } \\
(92)\end{array}$ & $\begin{array}{l}\mathrm{P} \\
\text { value }\end{array}$ & Adapters (168) & $\begin{array}{l}\text { Non-adapters } \\
(121)\end{array}$ & $\begin{array}{l}\mathrm{P} \\
\text { value }\end{array}$ & Adapters (106) & $\begin{array}{l}\text { Non-adapters } \\
(183)\end{array}$ & $\begin{array}{l}\mathrm{P} \\
\text { value }\end{array}$ \\
\hline $\begin{array}{l}\text { Rice yield per hectare } \\
\text { (t/ha) }\end{array}$ & $\begin{array}{l}4.18 \\
(3.40-4.48)\end{array}$ & $\begin{array}{l}3.12 \\
(2.89-3.90)\end{array}$ & & $\begin{array}{l}4.13 \\
(3.05-4.48)\end{array}$ & $\begin{array}{l}4.00 \\
(2.89-4.48)\end{array}$ & 30 & $\begin{array}{l}4.05 \\
(3.32-4.48)\end{array}$ & $\begin{array}{l}3.40 \\
(2.89-4.00)\end{array}$ & 789 \\
\hline $\begin{array}{l}\text { Farm gate price } \\
\text { (USD/ton) }\end{array}$ & $\begin{array}{l}168.00 \\
(135.28-216.45)\end{array}$ & $\begin{array}{l}160.00 \\
(135.28-216.45)\end{array}$ & 0.9310 & $\begin{array}{l}180.90 \\
(135.28-216.45)\end{array}$ & $\begin{array}{l}178.39 \\
(135.28-216.45)\end{array}$ & 0.1318 & $\begin{array}{l}168.90 \\
(135.28-216.45)\end{array}$ & $\begin{array}{l}162.34 \\
(135.28-216.45)\end{array}$ & 0.2830 \\
\hline $\begin{array}{l}\text { Total return per hectare } \\
\text { (USD/ha) }\end{array}$ & $\begin{array}{l}956.00 \\
(850.00-1180.10)\end{array}$ & $\begin{array}{l}789.00 \\
(690.90-1180.10)\end{array}$ & 0.0410 & $\begin{array}{l}890.50 \\
(856.00-1180.10)\end{array}$ & $\begin{array}{l}820.35 \\
(856.00-1180.10)\end{array}$ & 0.1716 & $\begin{array}{l}1050.00 \\
(856.00-1180.10)\end{array}$ & $\begin{array}{l}890.90 \\
(690.90-1180.00)\end{array}$ & 0.0809 \\
\hline $\begin{array}{l}\text { Total variable cash cost } \\
\text { per hectare (USD/ha) }\end{array}$ & $\begin{array}{l}355.50 \\
(335.00-378.10)\end{array}$ & $\begin{array}{l}316.04 \\
(300.80-378.10)\end{array}$ & 0.2985 & $\begin{array}{l}355.50 \\
(300.80-360.78)\end{array}$ & $\begin{array}{l}325.01 \\
(300.80-360.78)\end{array}$ & 0.7211 & $\begin{array}{l}325.50 \\
(336.50-378.10)\end{array}$ & $\begin{array}{l}358.60 \\
(300.80-378.10)\end{array}$ & 0.8119 \\
\hline $\begin{array}{l}\text { Total variable cost } \\
\text { per hectare (USD/ha) }\end{array}$ & $\begin{array}{l}420.26 \\
(380.00-580.00)\end{array}$ & $\begin{array}{l}435.50 \\
(380.00-592.11)\end{array}$ & 0.3439 & $\begin{array}{l}502.03 \\
(401.00-592.11)\end{array}$ & $\begin{array}{l}432.50 \\
(380.00-520.50)\end{array}$ & 0.0735 & $\begin{array}{l}430.05 \\
(380.00-458.00)\end{array}$ & $\begin{array}{l}446.50 \\
(380.00-592.11)\end{array}$ & 0.0743 \\
\hline $\begin{array}{l}\text { Profit per hectare } \\
\text { (USD/ha) }\end{array}$ & $\begin{array}{l}300.54 \\
(180.00-328.50)\end{array}$ & $\begin{array}{l}240.09 \\
(180.00-328.50)\end{array}$ & 0.0817 & $\begin{array}{l}318.65 \\
(180.00-328.50)\end{array}$ & $\begin{array}{l}295.50 \\
(180.00-328.50)\end{array}$ & 0.8569 & $\begin{array}{l}318.65 \\
(180.00-328.50)\end{array}$ & $\begin{array}{l}256.00 \\
(180.00-328.50)\end{array}$ & 0.0704 \\
\hline Benefit Cost Ratio & $\begin{array}{l}1.58 \\
(1.34-2.32)\end{array}$ & $\begin{array}{l}1.43 \\
(0.45-1.75)\end{array}$ & 0.0719 & $\begin{array}{l}1.66 \\
(0.56-2.32)\end{array}$ & $\begin{array}{l}1.47 \\
(0.45-2.20)\end{array}$ & 0.1126 & $\begin{array}{l}1.68 \\
(1.26-2.32)\end{array}$ & $\begin{array}{l}1.50 \\
(0.45-2.20)\end{array}$ & 0.0591 \\
\hline
\end{tabular}

Note. The values in parentheses are the range of respective variables.

Focused on adaptation option of rice variety changes, the study found that 106 farmers changed the early maturing and drought resistant varieties during last 5 years. It was observed that most of socioeconomic characteristics of two groups were not different, except the yield and profit of rice production. The yield and profit of adapter farm households were higher than that of the non-adapter group.

In summary, farm size, access to irrigation, yield, profit and total return were found to be higher in the case of adapters than that of non-adapters. Unlike the finding of some studies (Abid et al., 2015; Antwi-Agyei, Fraser, Dougill, Stringer, \& Simelton, 2012; Philip Antwi-Agyei et al., 2014), there were no statistical differences in almost of other socioeconomics characteristics of both groups such as education level, farming experience, etc.

\subsection{Determinants of Farmers' Choice on Specific Climate Adaptation Option}

The binary probit regression results are presented in Table 5 . The model was statistically significant and the probability value (Prob. $>\chi^{2}=0.0000$ ) showed that all the coefficients of variables in probit model have a difference of 0 and fit to the model. The model explained $51 \%$ of the variance in farmers' decisions to choose the adaptation of using farm machineries, $41 \%$ of the variance in farmers' decisions to use more agrochemicals, $59 \%$ of the variance in farmers' decisions to change rice varieties and $69 \%$ of the variance in decisions to use all these adaptations together. 
Table 5. Determinants of a farmer's choice to use a specific climate adaptation strategy

\begin{tabular}{|c|c|c|c|c|c|c|c|c|}
\hline & \multicolumn{2}{|c|}{ Farm machineries application } & \multicolumn{2}{|c|}{ More agrochemicals utilization } & \multicolumn{2}{|c|}{ Rice varieties changes } & \multicolumn{2}{|c|}{ Adaptation combination } \\
\hline & Coeff: & $\mathrm{P}>|\mathrm{z}|$ & Coeff: & $\mathrm{P}>|\mathrm{z}|$ & Coeff: & $\mathrm{P}>|\mathrm{z}|$ & Coeff: & $\mathrm{P}>|\mathrm{z}|$ \\
\hline \multicolumn{9}{|c|}{ Socioeconomics factors } \\
\hline SYF & 0.1089 & 0.5612 & 0.0793 & $0.0629 *$ & -0.0417 & 0.1033 & 0.2287 & $0.0362 * *$ \\
\hline RFE & 0.0791 & $0.0754 *$ & 0.0215 & $0.0618^{*}$ & 0.1028 & 0.2056 & 0.1208 & $0.0019 * * *$ \\
\hline FFL & -0.0981 & 0.8010 & 0.0764 & 0.7291 & 0.0072 & $0.0210 * *$ & 0.0190 & 0.4370 \\
\hline HDR & -0.0087 & 0.4926 & -0.0087 & 0.2167 & 0.0611 & 0.5478 & -0.1873 & 0.2116 \\
\hline FSH & 0.0516 & $0.0645 *$ & 0.3085 & $0.0752 *$ & -0.0148 & 0.4611 & 0.1118 & $0.0568 * *$ \\
\hline FIS & 0.0815 & 0.1690 & 0.0655 & 0.9122 & 0.3101 & $0.0716^{*}$ & 0.5133 & $0.0039 * * *$ \\
\hline \multicolumn{9}{|c|}{ Institutional factors } \\
\hline ATI & 0.0673 & $0.0411^{* *}$ & 0.0063 & 0.1254 & 0.0307 & $0.0000^{* * *}$ & 0.2788 & $0.0000 * * *$ \\
\hline ATC & 0.1758 & 0.8955 & 0.1758 & 0.8955 & -0.5178 & $0.0368 * *$ & -0.7480 & $0.0481 * *$ \\
\hline PAT & 0.0015 & 0.8750 & 0.0163 & $0.0787^{*}$ & 1.0761 & 0.4591 & 0.2691 & $0.0617^{*}$ \\
\hline ATW & 0.0197 & 0.2865 & 0.3175 & 0.2611 & 1.0157 & 0.1026 & 1.3230 & $0.0260 * *$ \\
\hline Intercept & 0.1097 & 0.5854 & -0.1953 & 0.5847 & -1.4509 & 0.1180 & -1.7797 & 0.1007 \\
\hline \multicolumn{2}{|c|}{ Prob. $>\chi^{2}$} & 0.0000 & & 0.0000 & & 0.0000 & & 0.0000 \\
\hline \multicolumn{2}{|c|}{ Log Livelihood } & -93.5016 & & -94.0148 & & 97.6590 & & 79.5920 \\
\hline \multicolumn{2}{|c|}{ Pseudo-R ${ }^{2}$} & 0.5103 & & 0.4102 & & 0.5914 & & 0.6906 \\
\hline
\end{tabular}

Note. ${ }^{* * *},{ }^{* *},{ }^{*}$ : significant at $1 \%, 5 \%$ and $10 \%$ level respectively.

From the model results, it was observed that access to irrigation (ATI), rice farming experience (RFE) and farm size (FSH) were the key factors for farmers' decision to use farm machineries. In this adaptation decision, rice farming experience and farm size were significant at $10 \%$ level, meaning that if their rice farming experience is higher and their farm size is larger, the farmers are likely to use more farm machineries in their farms. As regards to institutional factor, access to irrigation had a positive influence and significant at $5 \%$ level. It means that the probability of using farm machineries will be significantly increased by the farmers who can access to irrigation water.

Concerned with the adaptation option of more agrochemicals utilization, the explanatory variables such as education level of farmers (SYF), farmer's participation in agricultural training program (PAT) and farm size (FSH) influenced the decision of farm households to use it. The significant values of SYF, PAT and FSH expressed that the farmers are likely to use more agrochemicals in their farms if they were more educated, had larger farm size and access to agricultural training.

Regarding the factors influencing decision of changing rice varieties, it was found that irrigation access (ATI) was significantly different at $1 \%$ level, rice farming experience (RFE) at $5 \%$ level of significance. Moreover, participation to agricultural training (PAT), farm size (FSH) and farm income share (FIS) were significantly different at $10 \%$. It means that the farmers are likely to change their rice varieties if they are experienced farmers and they have access to irrigation, and training program, larger farm size and a larger portion of farm income.

When analyzing with the famers who used these adaptation options together, the binary probit model showed that rice farming experience (RFE), farm income share (FIS), access to irrigation (ATI) were statistically significant at $1 \%$ level; schooling years of farmer (SYF), farm size (FSH), access to credit (ATC) and access to weekly weather information (ATW) at $5 \%$ level of significant and participation in agricultural training program (PAT) at $10 \%$ level of significant. Therefore, if the farmers have more institutional supports i.e. the farmers have access to irrigation, credit and weather information, and other skills like more educated and farming experience, larger farm income share and farm size, they are likely to apply the combination of these adaptation measures.

Similar to these findings, Huang et al. (2015), Gutu et al. (2012), and Aymone Gbetibouo (2009) also report that access to weather information, agricultural credit, irrigation infrastructure, education level and experience of the farmer are the key determinant to farmers adaptation decision.

\subsection{Propensity Score Matching (PSM) on Agricultural Adaptation Options}

To realize the economic impact of agricultural adaptation option to farm households, PSM analysis with three different matchings was carried out. Table 6 describes the average treatment effect on treated group of PSM model. ATT showed the additional profit and yield for the adopter when they were using specific adaptation option. 
Table 6. Economic impact of using adaptation combination

\begin{tabular}{|c|c|c|c|c|c|c|}
\hline & \multicolumn{2}{|c|}{ Nearest Neighbour } & \multicolumn{2}{|c|}{ The Radius } & \multicolumn{2}{|c|}{ The Kernel } \\
\hline & ATT & $t$ value & ATT & t value & ATT & $t$ value \\
\hline \multicolumn{7}{|c|}{ Economic impact of farm machinery (timely operation) } \\
\hline Profit (USD/ha) & $32(28)$ & $1.7690^{*}$ & $27(39)$ & $1.8819^{*}$ & $30(29)$ & $1.6518^{*}$ \\
\hline Total return (USD/ha) & $67(101)$ & 3.1260 & $65(113)$ & 3.374 & $51(97)$ & $2.1890 *$ \\
\hline Total variable cost (USD/ha) & $-21(45)$ & 0.2387 & $-26(34)$ & $0.2110^{*}$ & $-28(31)$ & 0.3290 \\
\hline Productivity (ton/ha) & $0.58(0.03)$ & 2.4518 & $0.37(0.45)$ & 2.1381 & $0.44(0.12)$ & 2.9810 \\
\hline \multicolumn{7}{|c|}{ Economic impact of more agrochemicals utilization } \\
\hline Profit (USD/ha) & $21(53)$ & 1.198 & $26(71)$ & $1.130 *$ & $21(44)$ & 1.452 \\
\hline Total return (USD/ha) & $42(48)$ & $2.911 *$ & $47(65)$ & $2.011 *$ & $39(82)$ & $2.459 *$ \\
\hline Total variable cost (USD/ha) & $25(41)$ & $0.319 *$ & $30(46)$ & $0.413 *$ & $24(39)$ & $0.486^{*}$ \\
\hline Productivity (t/ha) & $0.13(0.24)$ & 1.982 & $0.11(0.22)$ & 1.947 & $0.19(0.32)$ & 1.991 \\
\hline \multicolumn{7}{|c|}{ Economic impact of rice variety changes } \\
\hline Profit (USD/ha) & $56(44)$ & $1.981 * * *$ & $62(87)$ & $2.130 * *$ & $64(47)$ & $2.116^{* *}$ \\
\hline Total return (USD/ha) & $102(108)$ & $2.080 *$ & $110(135)$ & $2.919 *$ & $109(118)$ & $3.001 * *$ \\
\hline Total variable cost (USD/ha) & $-32(40)$ & 0.381 & $-30(36)$ & 0.501 & $0.14(37)$ & 0.482 \\
\hline Productivity (ton/ha) & $0.37(0.04)$ & $1.786^{* *}$ & $0.41(0.32)$ & $1.984 *$ & $0.31(0.22)$ & $0.991 *$ \\
\hline \multicolumn{7}{|c|}{ Economic impact of using adaptation combination } \\
\hline Profit (USD/ha) & $108(110)$ & $1.1858 * * *$ & $102(97)$ & $2.3106^{* *}$ & $124(140)$ & $1.1180 * * *$ \\
\hline Total return (USD/ha) & $154(98)$ & $2.0124 * *$ & $158(114)$ & $2.0195^{* *}$ & $152(189)$ & $1.2180 * *$ \\
\hline Total variable cost (USD/ha) & $-42(56)$ & 0.4380 & $-25(42)$ & 0.6148 & $-27(47)$ & 0.8901 \\
\hline Productivity (ton/ha) & $0.91(0.52)$ & $1.1802 * *$ & $0.86(1.26)$ & $1.2409 *$ & $0.98(0.96)$ & $1.8106^{* *}$ \\
\hline
\end{tabular}

Note. ${ }^{* * *}, * *, *$ : significant at $1 \%, 5 \%$ and $10 \%$ level respectively, values in parentheses are standard errors.

Concerning the economic impact of using farm machineries, the results indicated that the profit of $32 \mathrm{USD} / \mathrm{ha}$ was significantly different at $10 \%$ level under Nearest neighbour category, showing the use of farm machineries has a certain impact on farmers' profit. The adapter farmers will gain additional profit of $32 \mathrm{USD} / \mathrm{ha}$ because of timely operation in their farming.

In radius matching, the positive impact was found in profit comparison and negative impact was in total variable cost comparison, which were significantly different at $10 \%$ level. The farm machineries users will get additional profit of $27 \mathrm{USD} / \mathrm{ha}$ and spend less $26 \mathrm{USD} / \mathrm{ha}$ of total variable cost, as a result of using farm machineries.

As per kernel matching, profit and total return comparisons were also statistically significant at $10 \%$ level, meaning that the farm machineries users will get additional $30 \mathrm{USD} / \mathrm{ha}$ profit and $51 \mathrm{USD} /$ ha total return than the situation if they did not use farm machineries.

For the impact of using more agrochemicals to farm income, the study reveals that total return comparison was significantly different at $10 \%$ level in nearest neighbour matching, meaning use of more agrochemicals had an impact on total return of rice production of adapter farmers. The adapters received more $42 \mathrm{USD} / \mathrm{ha}$ in their total return than the condition if they did not use it. As per the radius matching approach, three comparisons were statistically significant at $10 \%$ level. The adapter farmers received more $26 \mathrm{USD} /$ ha profit, additional $47 \mathrm{USD} / \mathrm{ha}$ total return and extra $30 \mathrm{USD} / \mathrm{ha}$ total variable cost than the condition if they did not use more agrochemicals. By the kernel matching, profit comparison was not significantly different, however, total return and total variable cost comparisons were significantly different at $10 \%$ level, meaning that the adapter farmers received more 39 $\mathrm{USD} / \mathrm{ha}$ in total return and occurred additional $24 \mathrm{USD} / \mathrm{ha}$ total variable cost.

Analysing the impacts of changing rice varieties to rice productivity and farm income, the study reveals that the impact to profit of changing rice varieties were $55 \mathrm{USD} / \mathrm{ha}$ by the nearest neighbour method, $62 \mathrm{USD} / \mathrm{ha}$ by radius matching and $64 \mathrm{USD} / \mathrm{ha}$ by kernel matching. The total return will be likely to increase as $102 \mathrm{USD} / \mathrm{ha}$, $110 \mathrm{USD} / \mathrm{ha}$ and $109 \mathrm{USD} / \mathrm{ha}$ by nearest neighbour, radius matching and kernel matching, respectively. Changing rice varieties gave an additional $0.31 \mathrm{t} / \mathrm{ha}$ to $0.41 \mathrm{t} / \mathrm{ha}$ of yield to the farmers. Therefore, the results showed the changes of rice varieties had a positive impact to the productivity, total return and profit of the adapter farms.

Dealing with how the adaptation combination had an impact on the productivity and profit of adapter farming, the positive and significant impacts of using that adaptation combination were observed 108-124 USD/ha profit, 152-158 USD/ha total return and 0.86-0.89 ton/ha yield by all three different matching of PSM. The study 
reveals that adaptation combination has greater impact on the productivity and profit than a single or individual adaptation itself. The finding supports the theorical assumption that the more adaptation combinations can build the better adaptive capacity of farm households.

\section{Conclusions and Policy Implication}

The erratic rainfall, especially dry spell period and unexpected rain during the critical crop growth stages, is the challenge threatening rice-based farming in study area. Uneven rainfall and changes during a season lead to changes in planting season and changes in crops to be grown (FAO, 2008). With the uncertain and uneven distribution of rain in the study area, the precise cropping calendar should be formulated based on farmer practices and the local climate trends by the DoA and other concerned organizations and disseminated back to the farmers via proper extension service.

To cope with current climate-related hazards, there are six major agricultural adaptations in the study area and the study reveals that rice varieties changes, more agrochemicals utilization and farm machinery's timely operation, build the betterment of farm households by improving productivity and net farm income. These local adaptation practices should be scaling up and/or scaling out to become climate smart farming through participatory approach, in line with current government policies of Myanmar Climate Smart Agriculture Strategy (2015), Myanmar Rice Sector Development Plan (2015) and Myanmar Agricultural Development Strategies (2017).

In each of single adaptation option itself, changing locally adaptable varieties has a significant positive impact on farm income and productivity. This farmer-practiced adaptation is consistent with the government priorities of adaptation program. As MCSA strategy stated that to increase resilience to climate change, a diversity of climate smart varieties will be developed in vulnerable area like flood or drought prone area, and moreover, in accordance with the seed sector development goal of Ministry of Agriculture, farmer participatory certified seed system should be encouraged to support the widely use of locally adaptable and economically viable varieties.

Together with the adaptation of changing varieties, the application of agrochemicals became one of adaptation measure to prevent yield losses from risk of climate stresses, such as pest and disease outbreak, soil erosion and soil fertility deterioration. However, use of more agrochemicals should be effective and safely manner together with integrated pest management and site-specific nutrient management. This local adaptation practice should be scaled up with IPM and SSNM, to be the nitrogen smart adaptation and low emission mitigation for future sustainability.

Facing with scarce and uncertain rainfall, timely operation is critically important in the farming system. To do so, application of farm machinery became important adaptation option and the study already proved that it has a significant impact on profit and productivity of a farm even under a certain climate stress. However, accessibility of farm machinery is not easy for all the farming communities. To strengthen farm mechanization, medium- and long-term loan for farm machinery should be supported as access to credit and loan is one of important factors determining adaptation decision. Myanmar agricultural development bank MADB should consider the mediumand long term long for farm mechanization process by feasible coordination with international organization. Currently Myanmar Economic Bank and JICA are initiating two-step loan program, providing long-term loan for small and medium enterprise development in Myanmar. It should enhance its project scope to encourage to small scale to large scale farmers to transform mechanised farming by providing mid- and long- term loan.

Moreover, the study shows the important of adaptation combination in farming system. Combination of adaptation measures results better adaptive capacity of the farm households by improving productivity and profit from the farm production than an individual adaptation itself. To fully utilize the benefit of adaptation, region-specific framework of inclusive climate change adaptation should be designed corresponding to climate stresses and farmer's practices in the particular area.

As a limitation of adaptation in the study area, current agricultural policies are more emphasis on rice and it is the challenge to the farmers to change other potential cash crops from rice, especially in KyautSe township. Rice cultivation need adequate amount of irrigation water and face crop failure if there is not enough irrigation. By substituting other potential crops like less water demanded cash crops, the transformation of crop structure and agricultural diversification should be considered as an appropriate suggestion to adapt changing rainfall in the growing season with the intention of secure crop income as well as crop productivity.

\section{Acknowledgements}

The authors would like to express a sincere gratitude to German Academic Exchange Service and Southeast Asian Regional Center for Graduate Study and Research in Agriculture for their scholarship to the first author 
and the International Foundation for Science for the research grant to this study. Authors are also grateful to the anonymous referees for their comments and suggestions that substantially improved the quality of the article.

\section{References}

Abid, M., Scheffran, J., Schneider, U. A., \& Ashfaq, M. (2015). Farmers' perceptions of and adaptation strategies to climate change and their determinants: The case of Punjab province, Pakistan. Earth System Dynamics, 6(1), 225-243. https://doi.org/10.5194/esd-6-225-2015

Antwi-Agyei, P., Fraser, E. D. G., Dougill, A. J., Stringer, L. C., \& Simelton, E. (2012). Mapping the vulnerability of crop production to drought in Ghana using rainfall, yield and socioeconomic data. Applied Geography, 32(2), 324-334. https://doi.org/10.1016/j.apgeog.2011.06.010

Antwi-Agyei, P., Stringer, L. C., \& Dougill, A. J. (2014). Livelihood adaptations to climate variability: Insights from farming households in Ghana. Regional Environmental Change, 14(4), 1615-1626. https://doi.org/ 10.1007/s10113-014-0597-9

Aymone Gbetibouo, G. (2009). Understanding Farmers' Perceptions and Adaptations to Climate Change and Variability: The Case of the Limpopo Basin, South Africa. International Food Policy Research Institute.

Barry, S., \& Mark, W. S. (2002). Adaptation Options in Agriculture to Climate Change: A Typology. Mitigation and Adaptation Strategies for Global Change, 7, 85-114. https://doi.org/10.1023/A:1015862228270

Chiotti, Q., Johnston, T. R. R., Smit, B., \& Ebel, B. (1997). Agricultural response to climate change: A preliminary investigation of farm-level adaptation in southern Alberta. In B. Ilbery, Q. Chiotti, \& T. Rickard (Eds.), Agricultural Restructuring and Sustainability: Ageographical perspective (pp. 167-183): Wallingford, CAB International.

Di Falco, S., Veronesi, M., \& Yesuf, M. (2011). Does Adaptation to Climate Change Provide Food Security: A Micro-Perspective from Ethiopia. American Journal of Agricultural Economics, 93(3), 829-846. https://doi.org/10.1093/ajae/aar006

El-Shater, T., Yigezu, Y. A., Mugera, A., Piggin, C., Haddad, A., Khalil, Y., ... Aw-Hassan, A. (2016). Does Zero Tillage Improve the Livelihoods of Smallholder Cropping Farmers? Journal of Agricultural Economics, 67(1), 154-172. https://doi.org/10.1111/1477-9552.12133

FAO. (2008). Water and the Rural Poor: Interventions for Improving Livelihoods in sub-Saharan Africa. Retrieved from Rome, Italy.

Gebrehiwot, T., \& van der Veen, A. (2013). Farm level adaptation to climate change: The case of farmer's in the Ethiopian highlands. Environmental Management, 52(1), 29-44. https://doi.org/10.1007/s00267-013-0039-3

Greene, W. H. (2000). Econometric Analysis (4th ed.). Upper Saddle River, NJ: Prentice Hall.

Gutu, T., Bezabih, E., \& Mengistu, K. (2012). Econometric analysis of local level perception, adaptation and coping strategies to climate change induced shocks in North Shewa, Ethiopia. International Research Journal of Agricultural Science and Soil Science, 2(8), 347-363.

Huang, J., Wang, Y., \& Wang, J. (2015). Farmers' Adaptation to Extreme Weather Events through Farm Management and Its Impacts on the Mean and Risk of Rice Yield in China. American Journal of Agricultural Economics, 97(2), 602-617. https://doi.org/10.1093/ajae/aav005

IPCC. (2007). Climate Change 2007. Impacts, Adaptation and Vulnerability. Contribution of Working Group II to the Fourth Assessment Report of the Intergovernmental Panel on Climate Change (pp. 7-22). Cambridge University Press, Cambridge, UK.

Khandker, S. R. (2010). Handboook on Impact Evaluation-Quantitative Method and Practice. The World Bank.

Kreft, S., David, E., Lukas, D., \& Livia, F. (2016). Global Climate Risk Index 2016: Who Suffers Most From Extreme Weather Events? Weather-related Loss Events in 2015 and 1996 to 2015. Bonn: Germanwatch e.V.

Nang Eimon, T., \& Cho Cho, S. (2012). Impact of Climate Change on Rural Livelihoods in Pakokku Township, Magway Region, Myanmar (M. Agr. Sc., Yezin Agricultural Univeristy, NayPyiTaw).

Nang, H., Nyo Mar, H., Yarzar, H., \& Shwe Mar, T. (2015). Myanmar Climate Smart Agriculture Strategy. CGIAR Research Program on Climate Translation Change, Agriculture, and Food Security in Southeast Asia. 
Priyanka, P., \& Herman, W. (2015). Adoption and impact of black pepper certification in India. Quarterly Journal of International Agriculture, 54(2), 133-161.

Rajendra, P. S., Nani, R., Lwin, M. M. S., \& Thida, T. (2018). Climate Change Adaptation Strategies in Agriculture: Cases from Southeast Asia. Sustainable Agriculture Research, 7(3), 39-51. https://doi.org/ 10.5539/sar.v7n3p39

Rosenbaum, P. R. A. R. D. B. (1983). The Central Role of the Propensity Score in Observational Studies for Causal Effects. Biometrika, 70, 41-55. https://doi.org/10.1093/biomet/70.1.41

Tun Oo, A., Van Huylenbroeck, G., \& Speelman, S. (2017). Determining factors for the application of climate change adaptation strategies among farmers in Magwe District, dry zone region of Myanmar. International Journal of Climate Change Strategies and Management, 9(1), 36-55. https://doi.org/10.1108/IJCCSM-092015-0134

UNFCCC. (2007). Climate Change: Impacts, Vulnerabilities and Adaptation in Developing Countries.

\section{Notes}

Note 1. Official press release of Ministry of Information and Ministry of Agriculture, stated in New Light of Myanmar Newspaper (specific time periods).

\section{Copyrights}

Copyright for this article is retained by the author(s), with first publication rights granted to the journal.

This is an open-access article distributed under the terms and conditions of the Creative Commons Attribution license (http://creativecommons.org/licenses/by/4.0/). 